\title{
Okul Öncesi Dönemdeki Çocukların Okula Uyum Düzeylerinin Çeşitli Değişkenler Açısından İncelenmesi*
}

\section{The Study of School Adjustment of Preschool Children in the Point of Some Variables}

\author{
Özlem Sevgi Kaya, Okul Öncesi Ögrretmeni,Cumhuriyet Anaokulu, ozsevgi kar@hotmail.com \\ Ege Akgün, Yrd. Doç. Dr. Ankara Üniversitesi, Eğitim Bilimleri Fakültesi, akgun@ankara.edu.tr
}

öZ. Bu araştırmada okul öncesi dönem çocuklarının okula uyum düzeyi ile mizaç, özsaygı, cinsiyet, yaş, okula devam durumu, kardeși olup olmama durumu değişkenleri arasındaki ilişki incelenmiștir. Araştırmada verilerin toplanmasında Okul Uyumu Öğretmen Değerlendirme Ölçeği, Çocuklar İçin Kısa Mizaç Ölçeği, Cassidy Kukla Görüşme Formu ve Demografik Bilgi Formu kullanılmıştır. Araştırmanın bulgularına göre okula uyum ölçeği alt boyutlarında, cinsiyet, yaş ve okula devam süresi değişkenlerinde anlamlı farklılık bulunurken kardeşi olup-olmama değişkeni ile anlamlı bir farklılık bulunmamıştır. Okul öncesi dönem çocukların çocuklar için kısa mizaç ölçeği alt boyutlarından ritmiklik alt boyutu ile okula uyum ölçeği kendi kendini yönetme alt boyutu arasında olumsuz yönde anlamlı ilişki bulunmuştur. Okul öncesi dönem çocukların genel özsaygı düzeyi puanları ile okula uyum ölçeği kendi kendini yönetme alt boyutu puanları arasında olumlu yönde anlamlı bir ilişki bulunmuştur. Okul öncesi dönem çocuklarının mizaç özellikleri ile öz saygı düzeyinin çocukların okula uyum düzeylerini açıklama oranı \%3' dür.

Anahtar Kelimeler. Okul Öncesi Dönem, Okula Uyum, Mizaç, Özsaygı

\begin{abstract}
In this study, it is examined that the relationship between the levels of pre-school children's school adjustment and the variables of self-esteem, temperament, gender, age, having siblings and attendance of school. Teacher Rating Scale of School Adjustment, the Short Temperament Scale for Children and Cassidy Puppet Interview Form are used to collect data. According to the findings, it is seen that there is a significant difference in the gender, age and attendance of school in the subscales of school adjustment. Whether having siblings doesn't make any significant difference between the levels of school adjustment. There is a meaningful negative relationship between the rhythmicity level of temperament traits and selfdirectedness is one of the subscales of school adjustment. Moreover, the positive meaningful relationship has found out between the score of preschool children's self-esteem levels and self-directedness which is subscale of school adjustment. The rate of temperament and self-esteem explain the school adjustment ratio as $3 \%$.
\end{abstract}

Keywords. Preschool Children, School Adjustment, Temperament, Self-esteem.

\section{SUMMARY}

Purpose and Significance: This article examines the relationship between the levels of pre-school children's school adjustment and the variables of self-esteem and temperament. Moreover, the levels of pre-school children's adjustment are relieved according to the variables which are sourced from the children themselves such as gender, age, having siblings and attendance of school.

Methodology: In this research, the relational model is used, which is one of the patterns of descriptive research. Study group of the research consisted of 200 pre-school children in Ankara. In order to gather the data, the Teacher Rating Scale of School Adjustment, the Short Temperament Scale for Children, Cassidy Puppet Interview Form, and the demographic information form were fulfilled. T test, correlation coefficient of Pearson, variance analysis and multiple regression analysis are made for analyzing the data.

Results: According to the findings of the study, there is a significant difference in the favor of girls for adjustment of school. Also, it is examined that there is a positive relationship between the age and the level of school adjustment and also the level of adjustment becomes higher when they are getting older. On the other hand, it is discovered that there is no relationship between the level of

\footnotetext{
*Bu çalışma “Okul öncesi dönemdeki çocukların okula uyum düzeylerinin çeşitli değişkenler açısından incelenmesi” başlıklı Yüks ek Lisans tez çalışmasının bir bölümünden özetlenerek hazırlanmış ve 13-15 Mayıs 2015 tarihleri arasında gerçekleştirilen "Uluslararası Eğitim Kongresi: Gelecek İçin Eğitim" başlıklı kongrede sözlü bildiri olarak sunulmuştur.
} 
school adjustment whether they have a sibling or not. The meaningful negative relationship is figured out between rhythmicity level of temperament traits and self-directedness, which is one of the subscales of school adjustment. Moreover, the positive meaningful relationship is found out between the scores of preschool children's self-esteem level and self-directedness, which is subscale of school adjustment. The rate of temperament and self-esteem explain the school adjustment ratio as 3\%. This percent is very low to explain the adjustment of school. In other words, there are influences of some other variables on preschool children's school adjustment, temperament and self-esteem.

Discussion and Conclusion: According to all these findings, it is observed that when the level of school adjustment of preschool children's is examined, there is a relationship between the variables such as gender, temperament and self-esteem; on the other hand, the other factors sourced from the family and the school, which influence the school adjustment; the variables such as the attitudes of parent, socio-economic level, the teacher characteristics, the school environment, the program of school adjustment is also important. In this respect, the studies which analyze the child, the school and the variables about the family altogether can affect the levels of their school adjustment by using longitudinal studies, the evaluation of school adjustment by using multiple data gathering techniques such as observation and consultation apart from the view of teacher's observation, improving the programs that support the adaptation by identifying the variables involving school adjustment which are good for preschool children. In this study, it has been found out that if there is a direct relationship between temperament, self-esteem and school adjustment. It is suggested to test and develop a model with negotiator variables such as self-regulation, emotion regulation and social capability in the following studies.

\section{GÍRIS}

Çocuğun eğitim yaşamının başlangıcında yer alan okul öncesi döneminde okula uyum süreci sonraki okul deneyimlerini ve okul öncesi eğitimden etkin bir biçimde faydalanmayı etkileyebileceğinden dolayı önemli bir süreçtir. Okul öncesi eğitime başlayan çocuklar için evden okula bir geçiş niteliği de taşıyan bu süreç öğretmenler ve akranlar ile ilişkiler, öğrenme etkinliklerine katılım, kurallara ve okulun beklentilerine uygun davranışlar sergileme gibi alışkanlıkların geliştirilmesi için bir hazırlık dönemidir. Okula uyum, çocuğun girdiği ortamdan sosyal ve akademik olarak yarar sağlaması olarak tanımlanabilir. Bilişsel becerilerin yanında çocukların duyguları, tutumları ve çevresi ile ilişkilerini içeren dinamik bir süreç olarak da ifade edilebilir (Birch ve Ladd, 1997; Oktay ve Polat-Unutkan, 2005). Okula uyumu etkileyebilecek faktörler çocuk, aile ve okul ortamı ile ilişkili etkenler olarak gruplanabilir. Çocuğun okula başarılı bir geçiş sağlaması için birbirini destekleyen bu üç boyutun birlikte çalışması önem taşımaktadır (UNICEF, 2012).

Okulun çocuğu kabul süreci okula uyumu belirleyebilecek önemli bir değişkendir. Eğitim kurumlarının yeni başlayan çocukların eğitim sistemine dahil olmalarına ve uyum sağlamalarına yardımcı olmak amacı ile gerekli tedbirleri alması gerekmektedir. İnan ve İnan (2015) çocukların ellerini ve akıllarını kullanmaya teşvik eden eğitim sisteminin, kalplerine hitap edilen bir eğitim ortamının özellikle okul öncesi dönemde çocuklar için uygun olduğunu belirtmektedir. Çocukların okula uyum sürecinde çocukları aktif tutan, düşünmeye teşvik eden, ilgilerini çeken, okulu sevmelerini sağlayan eğitim yöntem ve teknikleri olarak tanımlanabilecek faktörlerin, çocukların okula uyumunu arttırdı̆̆ı görülmektedir.

Çocuğun gelişimi ve eğitimi ile ilişkili olarak önemli bir diğer bileşen olan aile özellikleri ve ailenin çocuğu okula hazırlaması da çocuğun okula uyumunda önem taşımaktadır. Bu özellikler arasında anne çocuk ilişkisi, bağlanma özellikleri, ailenin eğitim ve ekonomik durumu, çocuğun okula hazırlanma durumu gibi değişkenler sayılabilir. Aile ortamı ve sosyal çevre çocuğa sağladığı olanaklar ve yașantılarla okula hazırlıklı olmada önemli bir rol oynamaktadır. Çocuğun yeni sosyal çevrenin beklentilerini karşılayabilmesi ve bu yeni ortama uyum sağlayabilmesi belli bir düzeyde hazır bulunuşluğu gerektirmektedir. Desteklenmiş çevrelerden gelen çocukların okula daha hazır 
olarak başladıklarına ve okulda başarılı olma olasılıklarının daha yüksek olduğuna inanılmaktadır (Erkan, 2011).

Okula uyum ile ilişkili aile ve okul ile ilişkili özellikler yanında diğer önemli değiş̧ken de çocuğun bireysel özellikleridir. Bu özelliklerden bazıları ise yaş, cinsiyet, okula devam süresi, kardeş durumu mizaç ve özsaygı olarak sayılabilir. Docckett ve Perry (2003) ebeveynler, öğretmenler ve çocuklar ile yaptıkları araştırmada okula geçişte gelişmesi gerekli sekiz önemli alandan birini mizaç olarak belirtmişlerdir. Okula uyum ile ilişkili olduğu düşünülen ve çocuğun mizacın kalıtımsal olarak aktarılan, bebeklik döneminden başlayarak gözlenebilen, çevre tarafından biçimlendirilen ve nispeten kararlı kişilik yapılarından biri olduğu ifade edilmektedir (Chess ve Thomas, 1986; Kagan, 2002; Strelau, 2002). Bu alanda yapılan araștırmalara dayanılarak mizacın dokuz boyutu; aktivite düzeyi, ritmiklik, yaklaşma/çekilme, uyum sağlayabilirlik, duyusal eşik, yoğunluk, duygu durumu, dikkatte kayma, sebât olarak sıralanmaktadır (Chess ve Thomas, 1986). Bu özellikler doğrultusunda Thomas ve arkadaşları çocuklarda mizaç özelliklerine göre üç grup belirlemişlerdir: Birinci grup uyumlu, yeni deneyimlere ve ortamlara kolayca geçiş yapabilen, "kolay" mizaca sahip çocuklar; ikinci grup beslenme ve uyku alışkanlıkları düzensiz, yeni insanlar ve durumlara karşı korkulu, çabuk sinirlenen, "zor" mizaca sahip çocuklar ve üçüncü grup yeni ortam ve durumlara karşı çekingen, yavaş uyum sağlayabilen, "yavaş tepkili" mizaca sahip olan çocuklardır. Tam olarak bir kategori özelliklerini göstermeyen ancak farklı kategorilerin özelliklerinden bazılarına sahip çocuklar da bulunmaktadır (Akt. Kristal, 2005).

Okul başarısı ve sosyal davranış gibi çeşitli özelliklerin belirleyicisi olabilen mizaç, çocukların farklı gelişim alanlarında önemli rol oynamaktadır (Rothbart, Ahadi ve Evans, 2000). Araştırmalarda çocukların mizaç özellikleri ile davranış sorunları, akran kabulü, arkadaş seçimi ve sosyal yeterlilik, okul başarısı, öz-düzenleme ve öz-yeterlik kapasitesi, okulu sevme gibi değiş̧kenler ile öğrenci-öğretmen etkileşimi arasında ilişki olduğu bulunmuştur. Diğer bir deyişle mizaç çocuğun kendine özgü davranış stilini belirlemekte ve çocuğun bireyselliği hakkında bilgi vermektedir (Rothbart, Derryberry ve Hershey, 2000; Gleason, Gower, Hohmann ve Gleason, 2005; Kristal, 2005; Liew, McTigue, Barrois ve Hughes, 2008; Eisenberg vd., 2009; Joyce, 2010; Zhou, Main ve Wang, 2010; Curby, Rudasill, Edwards ve Koraly, 2011; Valiente, Swanson ve Chalfant, 2012; Yoleri, 2014a).

Rutter (1987) karmaşık bir süreç olarak tanımladığı okula uyum süreci için stres, kalıtsal ve yaşantısal bireysel farklılıklar, telafi edici deneyimler, çevre niteliği ve firsatlar gibi özelliklerin yanı sıra özsaygı ve başa çıkma becerilerinin de önemli olduğunu ifade etmektedir. Bu doğrultuda çocuğun okula uyumu ile ilişkili olabilecek bir diğer değişken olan özsaygı, çevresiyle etkileşim ve deneyimlerine bağlı olarak gelişen bireyin kendi özelliklerine yönelik duyguları, kendisini beğenme, benimseme, değerli ve sevilmeye değer bulma gibi değerlendirmeleri, kendini kabul ve saygı düzeyi olarak tanımlanabilir (Geçtan, 1984; Schunf, 2009). Olumlu özsaygıyıya sahip çocukların akran ilişkilerinin olumlu ve öğrenmede güdülenme düzeylerinin yüksek olduğu bilinmektedir (Coolahan, Fantuzzo, Mendez ve McDermott, 2000). Lindsey ve Colwell (2003) okul öncesi dönem çocukları ile gerçekleştirdiği boylamsal çalışmada çocukların duygusal yeterliğe ait becerilerinin akranlarıyla kurdukları ilişkilerini etkileyebildiğini göstermektedir. Duygusal yeterliğe sahip çocukların başkalarına yardım amaçlı sosyal davranışlar sergiledikleri ve akranlarıyla işbirliğine dayalı oyunlar oynadıkları belirlenmiștir. Bu özellikler doğrultusunda düşük özsaygı düzeyine sahip çocukların okula uyumda zorluk yaşayabilecekleri düşünülebilir.

Alan yazında okul öncesi dönem çocukların özsaygı düzeyi ile ilgili çalışmalara bakıldığında özsaygıyı etkileyebilecek değișkenlerin belirlenmesi ile ilgili çalışmaların yer aldığı görülmektedir (Dikici, 1998; İkiz, 2009; Sarıca, 2010). Özsaygının ilişkili olabileceği değişkenlerle ilgili olarak Dündar (2010) çalışmasında okulöncesi dönem çocuklarının benlik algıları ile bilişsel performansları arasındaki ilişkiyi incelemiștir. Ancak çocukların okula uyumu ile özsaygı düzeyi arasındaki ilişkilerin belirlendiği bir çalışmaya rastlanmamıştır.

Okul öncesi eğitime yeni başlayan çocukların okula uyumları okul öncesi eğitimden yararlanmalarını sağlayan öncelikli özelliklerden birisidir. Bu nedenle çocukların okula uyumlarını etkileyebilecek faktörlerin belirlenmesi uyumu destekleyen ve kolaylaştıran 
müdahale çalışmalarının planlanmasında önemli bir unsurdur. Okula uyumu belirleyen çocuk, aile ve okul ile ilişkili çok çeşitli değişkenler bulunmaktadır. Bu araştırmada okula uyumu etkileyebilecek faktörlerden alan yazında az sayıda çalıșmada yer alan cinsiyet, yaș, okula devam durumu, kardeşi olma durumu çocuğun mizaç ve özsaygı özellikleri gibi çeşitli değiş̧enler ele alınmıştır. Çalışmada çocuğun farklı özelliklerine ilişkin değişkelere yer verilmesi önem taşımaktadır. Bu değişkenlerin çocuğun okula uyumu ile ilişkisinin ayrı ayrı değerlendirilmesinin yanında uyum ile ilişkisini birlikte yordama özelliklerinin değerlendirilmesinin alan yazına katkı sağlayacağı düşünülmektedir. Bu doğrultuda araștırmanın amacl; okul öncesi dönem çocuklarının okula uyum düzeyleri ile mizaç, özsaygı, cinsiyet, okula devam, yaş ve kardeş durumu değişkenleri arasındaki ilişkinin incelenmesidir.

Bu amaç doğrultusunda aşağıdaki alt amaçlar incelenmiştir.

1. Okul öncesi dönem çocuklarının okula uyumu;

- cinsiyete göre anlamlı farklılık göstermekte midir?

- yaşa göre anlamlı farklılık göstermekte midir?

- okula devam durumuna göre anlamlı farklılık göstermekte midir?

- kardeşi olup olmama durumuna göre anlamlı farklılık göstermekte midir?

2. Okul öncesi dönem çocuklarının okula uyum düzeyleri ile

- mizaç özellikleri arasında anlamlı bir ilişki var mıdır?

- özsaygı düzeyleri arasında anlamlı bir ilişki var mıdır?

3. Okul öncesi dönem çocuklarının mizaç özellikleri ve özsaygı düzeyleri, okula uyum düzeylerini anlamlı bir şekilde yordamakta mıdır?

\section{Araştırma Deseni}

\section{YÖNTEM}

Araştırmanın amaçları doğrultusunda, betimsel araştırma desenlerinden ilişkisel tarama modeli kullanılmıştır. İliş̧kisel Araştırma Modeli tek bir grup içindeki değişkenler arasındaki iliş̧ileri araştırmayı amaçlamaktadır (Büyüköztürk, Çakmak, Akgün, Karadeniz ve Demirel, 2010).

\section{Çalışma Grubu}

Araştırmanın çalışma grubunu, 2013-2014 eğitim öğretim yılında Ankara-Çankaya'da bir bağımsız anaokulunda eğitimine devam eden 48-72 aylık 200 çocuk oluşturmaktadır. Çalışma grubu, seçkisiz olmayan örnekleme yöntemlerinden, uygun örnekleme yöntemi ile seçilmiştir. Kazara ya da elverişli örnekleme ismi ile de anılan bu örnekleme yöntemi araştırmanın amacına uygun gruba ulaşılması temel amaçtır (Büyüköztürk ve diğerleri, 2010). Buna göre araştırmaya katılmak konusunda gönüllü olan, zaman ve ulaşım açışında kolay ulaşılabilen bir okul araştırmanın kapsamına dahil edilmiş ve okulda eğitimine devam eden 48-72 aylık çocuklar örneklem grubunda yer almıştır. almaktadır.

Çalışma grubunda yer alan çocukların kişisel özelliklerine ait bilgiler Tablo 1 de yer

Tablo 1. Araștırmaya Katılan Çocukların Demografik Özellikleri

\begin{tabular}{|c|c|c|c|}
\hline Değişken & & $\mathbf{f}$ & $\%$ \\
\hline \multirow{2}{*}{ Cinsiyet } & $\mathrm{Kiz}$ & 92 & 46,0 \\
\hline & Erkek & 108 & 54,0 \\
\hline \multirow{2}{*}{ Yaş (ay) } & $48-60$ & 91 & 45,5 \\
\hline & $61-72$ & 109 & 54,5 \\
\hline \multirow{2}{*}{ Kardeși olup olmama durumu } & Kardeşi var & 128 & 64,0 \\
\hline & Kardeşi yok & 72 & 36,0 \\
\hline \multirow{4}{*}{ Okula devam durumu } & 6 aydan az & 37 & 18,5 \\
\hline & 7-12ay & 37 & 18,5 \\
\hline & 13-18 ay & 53 & 26,5 \\
\hline & 19 ay ve üzeri & 77 & 38,5 \\
\hline
\end{tabular}




\section{Veri Toplama Araçları}

Okul Uyumu Öğretmen Değerlendirme Ölçeği: Ladd, Kochenderfer ve Coleman (1996) tarafından okula uyum becerilerini ölçme amacıyla geliştirilen ölçek, 27 madde ve dört alt ölçekten oluşmaktadır. Ölçeğin içtutarlılık katsayıları okulu sevme .89, işbirlikli katılım .92, okuldan kaçınma .74 ve kendi kendini yönetme .91 olarak bulunmuştur (Birch ve Ladd, 1997). Önder ve Gülay (2010) tarafından Türkçeye uyarlaması yapılan form 25 maddeden oluşmaktadır. Ölçeğin uyarlama çalışmasına göre alt boyutlarının içtutarlık katsayıları okulu sevme .81, işbirlikli katılım .84, okuldan kaçınma.73 ve kendi kendini yönetme .67 olarak bulunmuştur. Ayrıca ölçeğin test tekrar test uygulamaları arasında olumlu yönde anlamlı ve yüksek bir ilişki olduğu görülmektedir ( $r=.97$ p<.01). Öğretmenler tarafından doldurulan ölçekteki her madde "Uygun Değil", "Uygun" ve "Tamamen Uygun" ifadeleriyle değerlendirilmektedir. Bu çalışmada ölçeğin içtutarlılık katsayıları hesaplanmış ve okulu sevme .67, işbirlikli katılım .88, okuldan kaçınma .74 ve kendi kendini yönetme .63 olarak bulunmuştur.

Çocuklar için Kısa Mizaç Ölçeği: Prior, Sanson ve Oberklaid (1989) tarafından erken çocukluktaki mizaç özelliklerinin değerlendirilmesi amacıyla geliştirilen Ölçek Sıcakkanlılık (Çocuğum ilk defa tanıştığı çocuklara karşı utangaçtır.), Sebatkarlık (Çocuğum, yeni bir işe geçmeden önce başlamış olduğu işini tamamlamayı sever.), Ritmiklik (Çocuğum her gün, hemen hemen aynı zamanda bir şeyler atıştırmak ister.) ve Tepkisellik (Çocuğum bir işle uğraşırken, üzüldüğü ya da canı sıkıldığında, onu yere atar, ağlar, kapıları çarpar.) olmak üzere dört alt boyuttan ve 30 maddeden oluşmaktadır. Anne babalar tarafından doldurulan ve her maddede çocuğun belirlenen davranışı ne sıklıkta gösterdiğinin değerlendirildiği altılı likert tipindeki ölçeğin Türk kültürüne uyarlaması Yağmurlu ve Sanson (2004) tarafından gerçekleştirilmiştir. Baydar, Küntay, Gökşen, Yağmurlu ve Cemalcılar (2008) tarafından tekrar gözden geçirilen ölçeğin iç tutarlık puanları sıcakkanlılık için .66, tepkisellik için .75, sebatkarlık için .75 ve ritmiklik için .51 olarak bulunmuştur. Bu çalışma için ölçeğin içtutarlılık katsayıları hesaplanmış ve sıcakkanlılık için .62, tepkisellik için .68, sebatkarlık için .79 ve ritmiklik için .53 olarak bulunmuştur

Cassidy Kukla Görüşme Formu: Cassidy tarafından (1988) okul öncesi dönem çocukların özsaygı düzeylerini belirleme amacıyla geliştirilen Form 20 sorudan oluşmaktadır. Dikici (1998) tarafından Türkçeye uyarlanan Formun güvenirliği Pearson Momentler Çarpımı Formülü ile hesaplanmıştır. Bunun sonucunda; olumlu kategorisinde elde edilen değişmezlik katsayısı .96, olumsuz kategorisinde .88, açık kategorisinde .84 ve mükemmel kategorisinde .84 olarak bulunmuştur. Cassidy Kukla Görüşme Formu'nun İç tutarlık katsayısı hesaplanmış ve benliğin olumluluğu (olumlu/olumsuz) ile benliğin açıklığı (açı/ mükemmel) kategorileri arasında tutarlık katsayılarının birbirlerini .55 oranında desteklediği bulunmuştur. Bu çalışma için formun içtutarlılık katsayısı benliğin açıklığı için .77 ve benliğin olumluluğu için .56 olarak bulunmuştur.

\section{Verilerin Toplanması}

Araştırmada verilerin toplanmaya başlanmasından önce gerekli izinler alınmıștır. Daha sonra çalışmanın amacına uygun olarak seçilen ölçeklerden Okul Uyumu Öğretmen Değerlendirme Ölçeği çocukların öğretmenleri tarafından, Çocuklar için Kısa Mizaç Ölçeği çocukların anne-babaları tarafından doldurulmuştur. Cassidy Kukla Görüşme Formu okul içinde seçilen sessiz bir ortamda, çocuklarla gerçekleştirilen bireysel görüşmelerin video kaydı alınarak bir araştırmacı tarafından doldurulmuştur.

\section{Verilerin Analizi}

Araştırmanın amaçlarına yönelik olarak verilerin test edilmesinde ilk olarak Normallik varsayımının sınanmasında Kolmogorov-Smirnov (K-S) testi ve veri setinin homojenliğini test etmede Levene istatistiği kullanılmıştır. Yapılan Kolmogorov-Smirnov testi sonucu, verilerin normal dağılım gösterdiği ( $p>.05)$ ve Levene testi sonucu $(F=0.969 ; p=0.326)$ varyansların homojen bir dağllım gösterdiği belirlenmiştir. Buna göre okula uyumun cinsiyet, yaş, okula devam durumu ve kardeş sayısına göre belirlenmesinde t Testi ve Varyans analizi kullanılmıştır. Ayrıca okula uyum ve mizaç ve özsaygı arası ilişkinin ayrı ayrı değerlendirilmesinde Pearson Korelasyon 
Katsayısı ve mizaç ve özsaygının birlikte okula uyumu yordama düzeyinin belirlenmesinde Çoklu Regresyon Analizi kullanılmıştır. Verilerin analizinde anlamlılık değeri $p<.05$ ve $p<.01$ olarak alınmıştır.

\section{BULGULAR}

Araştırmanın bulgular bölümünde ilk olarak cinsiyet, yaş, okula devam durumu ve kardeşi olup olmama durumuna göre okula uyum düzeylerine ilişkin bulgulara yer verilmiştir. Ardından Okul öncesi dönem çocuklarının okula uyum düzeyleri, mizaç özellikleri ve öz saygı düzeyleri arasındaki ilişkiyi belirten sonuçlar gösterilmiştir.

Tablo 2. Okul Uyumu Öğretmen Değerlendirme Ölçeği Puanlarının Cinsiyete Göre t Testi Sonuçları

\begin{tabular}{|c|c|c|c|c|c|c|c|}
\hline & Cinsiyet & $\mathbf{n}$ & $\bar{X}$ & $S$ & Sd & t & $\mathbf{P}$ \\
\hline \multirow{2}{*}{$\begin{array}{l}\text { İşbirlikli } \\
\text { katılım }\end{array}$} & $\mathrm{Kiz}$ & 92 & 25,8 & 3,1 & \multirow{2}{*}{198} & \multirow{2}{*}{3,6} & \multirow{2}{*}{$0,00^{*}$} \\
\hline & Erkek & 108 & 23,9 & 4,1 & & & \\
\hline \multirow{2}{*}{$\begin{array}{l}\text { Okuldan } \\
\text { kaçınma }\end{array}$} & $\mathrm{Kuz}$ & 92 & 4,5 & 1,3 & \multirow{2}{*}{198} & \multirow{2}{*}{$-7,14$} & \multirow{2}{*}{0,476} \\
\hline & Erkek & 108 & 4,6 & 1,4 & & & \\
\hline \multirow{2}{*}{$\begin{array}{l}\text { Kendi kendini } \\
\text { yönetme }\end{array}$} & $\mathrm{Klz}$ & 92 & 8,7 & 1,4 & \multirow{2}{*}{198} & \multirow{2}{*}{0,198} & \multirow{2}{*}{$0,00^{*}$} \\
\hline & Erkek & 108 & 7,9 & 1,3 & & & \\
\hline \multirow[t]{2}{*}{ Okulu sevme } & $\mathrm{Klz}$ & 92 & 10,6 & 1,1 & \multirow{2}{*}{198} & \multirow{2}{*}{0,841} & \multirow{2}{*}{0,401} \\
\hline & Erkek & 108 & 10,4 & 1,09 & & & \\
\hline \multirow{2}{*}{$\begin{array}{l}\text { Genel uyum } \\
\text { düzeyi }\end{array}$} & $\mathrm{Klz}$ & 92 & 53,71 & 4,5 & \multirow{2}{*}{198} & \multirow{2}{*}{4,004} & \multirow{2}{*}{$0,00^{*}$} \\
\hline & Erkek & 108 & 50,8 & 5,5 & & & \\
\hline
\end{tabular}

${ }^{*} \mathrm{p}<.01$ Tablo 2'de cinsiyete göre işbirlikli katılım $\left(\mathrm{t}_{(198)}=3.6, \mathrm{p}<.01\right)$, kendi kendini yönetme $\left(\mathrm{t}_{(198)}=0.198, \mathrm{p}<.01\right)$ alt boyutları ve genel uyum düzeyleri $\left(\mathrm{t}_{(198)}=4.004, \mathrm{p}<.01\right)$ arasinda kiz çocukların lehine anlamlı fark bulunduğu görülmektedir. Okuldan kaçınma $\left(\mathrm{t}_{(198)}=-.14, \mathrm{p}>.01\right)$ ve okulu sevme $\left(\mathrm{t}_{(198)}=0.841, \mathrm{p}>.01\right)$ alt boyutları arasında anlamlı bir fark bulunmamıştır. $\mathrm{Bu}$ bilgiler ışığında, cinsiyetin okula uyumda önemli bir değişken olduğu sonucu çıkarılabilir.

Tablo 3. Okul Uyumu Öğretmen Değerlendirme Ölçeği Puanlarının Yaşa Göre t Testi Sonuçları

\begin{tabular}{|c|c|c|c|c|c|c|c|}
\hline & $\begin{array}{l}\text { Yaş } \\
\text { (ay) }\end{array}$ & n & $\bar{X}$ & $S$ & Sd & $\mathbf{t}$ & $\mathbf{P}$ \\
\hline \multirow[t]{2}{*}{ İşbirlikli katılım } & $48-60$ & 91 & 24,08 & 4,05 & \multirow{2}{*}{198} & \multirow{2}{*}{$-2,5$} & \multirow{2}{*}{$0,013^{*}$} \\
\hline & $60-72$ & 109 & 25,44 & 3,57 & & & \\
\hline \multirow{2}{*}{$\begin{array}{l}\text { Okuldan } \\
\text { kaçınma }\end{array}$} & $48-60$ & 91 & 4,59 & 1,34 & \multirow{2}{*}{198} & \multirow{2}{*}{$-0,15$} & \multirow{2}{*}{0,88} \\
\hline & $60-72$ & 109 & 4,62 & 1,47 & & & \\
\hline \multirow{2}{*}{$\begin{array}{l}\text { Kendi kendini } \\
\text { yönetme }\end{array}$} & $48-60$ & 91 & 8,27 & 1,53 & \multirow{2}{*}{198} & \multirow{2}{*}{$-0,18$} & \multirow{2}{*}{0,85} \\
\hline & $60-72$ & 109 & 8,31 & 1,33 & & & \\
\hline \multirow[t]{2}{*}{ Okulu sevme } & $48-60$ & 91 & 10,52 & 1,26 & \multirow{2}{*}{198} & \multirow{2}{*}{$-0,08$} & \multirow{2}{*}{0,93} \\
\hline & $60-72$ & 109 & 10,54 & 1,3 & & & \\
\hline \multirow{2}{*}{$\begin{array}{l}\text { Genel uyum } \\
\text { düzeyi }\end{array}$} & $48-60$ & 91 & 51,26 & 5,17 & \multirow{2}{*}{198} & \multirow{2}{*}{$-2,16$} & \multirow{2}{*}{$0,031^{*}$} \\
\hline & $60-72$ & 109 & 52,88 & 5,34 & & & \\
\hline
\end{tabular}

*p<.05 Tablo 3'e göre okul öncesi dönemdeki çocukların yaşlarına göre işbirlikli katılım $\left(\mathrm{t}_{(198)}=\right.$ $2.5, \mathrm{p}<.05)$ ve genel uyum düzeylerinde $\left(\mathrm{t}_{(198)}=-2.16, \mathrm{p}<.05\right)$, anlamlı fark bulunurken okuldan kaçınma $\left(\mathrm{t}_{(198)}=-0.15, \mathrm{p}>.05\right)$, kendi kendini yönetme $\left(\mathrm{t}_{(198)}=-0.18, \mathrm{p}>.05\right)$ ve okulu sevme $\left(\mathrm{t}_{(198)}=\right.$ $-0.08, p>.05$ ) alt boyutları ile yaş değişkeni arasında anlamlı fark bulunamamıştır. Büyük yaş 
grubu çocukların okula uyum düzeyleri, işbirlikli katılım ve genel uyum düzeyi alt boyutlarında küçük yaş grubu çocuklara göre anlamlı düzeyde yüksektir.

Tablo 4. Okul Uyumu Öğretmen Değerlendirme Ölçeği Puanlarının Okula Devam Durumuna Göre ANOVA Sonuçları

\begin{tabular}{|c|c|c|c|c|c|c|c|}
\hline & $\begin{array}{c}\text { Varyansın } \\
\text { Kaynağı }\end{array}$ & $\begin{array}{l}\text { Kareler } \\
\text { Toplamı }\end{array}$ & sd & $\begin{array}{l}\text { Kareler } \\
\text { Ortalaması }\end{array}$ & $\mathbf{F}$ & $\mathbf{P}$ & Anlamlı Fark \\
\hline \multirow{3}{*}{$\begin{array}{l}\text { İșbirlikli } \\
\text { katılım }\end{array}$} & Gruplarararası & 57,939 & 3 & 19,313 & \multirow{3}{*}{1,137} & \multirow{3}{*}{0,335} & \multirow{3}{*}{ - } \\
\hline & Gruplariçi & 2980,256 & 196 & 15,205 & & & \\
\hline & Toplam & 3038,195 & 199 & & & & \\
\hline \multirow{3}{*}{$\begin{array}{l}\text { Okuldan } \\
\text { kaçınma }\end{array}$} & Gruplarararası & 28,999 & 3 & 9,666 & \multirow{3}{*}{3,51} & \multirow{3}{*}{$0,016^{*}$} & \multirow{3}{*}{$\begin{array}{l}* 6 \text { ay ve }- \text { ile } 7-12 \text { ay } \\
{ }^{*}-12 \text { ay ile } 13-18 \text { ay }\end{array}$} \\
\hline & Gruplariçi & 688,021 & 196 & 3,510 & & & \\
\hline & Toplam & 717,020 & 199 & & & & \\
\hline \multirow{3}{*}{$\begin{array}{l}\text { Kendi } \\
\text { kendini } \\
\text { yönetme }\end{array}$} & Gruplarararası & 16,785 & 3 & 5,595 & \multirow{3}{*}{0,089} & \multirow{3}{*}{0,96} & \multirow{3}{*}{ - } \\
\hline & Gruplariçi & 1285,195 & 196 & 6,557 & & & \\
\hline & Toplam & 1301,980 & 199 & & & & \\
\hline \multirow{3}{*}{$\begin{array}{l}\text { Okulu } \\
\text { sevme }\end{array}$} & Gruplarararası & 4,423 & 3 & 1,474 & \multirow{3}{*}{1,55} & \multirow{3}{*}{0,201} & \multirow{3}{*}{ - } \\
\hline & Gruplariçi & 250,857 & 196 & 1,280 & & & \\
\hline & Toplam & 255,280 & 199 & & & & \\
\hline \multirow{3}{*}{$\begin{array}{l}\text { Genel } \\
\text { uyum } \\
\text { düzeyi }\end{array}$} & Gruplarararası & 29,126 & 3 & 9,709 & \multirow{3}{*}{0,34} & \multirow{3}{*}{0,796} & \\
\hline & Gruplariçi & 5593,669 & 196 & 28,539 & & & \\
\hline & Toplam & 5622,795 & 199 & & & & \\
\hline
\end{tabular}

$* \mathrm{p}<.05$

Tablo 4'de gösterilen sonuçlara göre, okul öncesi dönem çocuklarının okula devam durumu ile okuldan kaçınma alt boyutları arasında anlamlı fark bulunmuştur $\left(\mathrm{F}_{(3-196)}=3.51\right.$, $\mathrm{p}<.05)$, İşbirlikli katılım $\left(\mathrm{F}_{(3-196)}=1.137, \mathrm{p}>.05\right)$, okulu sevme $\left(\mathrm{F}_{(3-196)}=1.55, \mathrm{p}<.05\right)$, kendi kendini yönetme $\left(\mathrm{F}_{(3-196)}=0.089, \mathrm{p}>.05\right)$ ve genel uyum düzeyi $\left(\mathrm{F}_{(3-196)}=0.34, \mathrm{p}>.05\right)$ puanları arasında anlamlı bir fark bulunamamıştır. Okula uyum düzeylerinin alt boyutu olan okuldan kaçınma davranışlarının okula devam ettikleri ilk aydan sonra artış gösterdiği daha sonra düşüş yaşandığı sonuçlarına ulaşılmıştır. Çocukların okula devam ettikleri süre içinde uyum düzeylerinde değişiklik olabileceği söylenilebilir.

Tablo 5. Okul Uyumu Öğretmen Değerlendirme Ölçeği Puanların Kardeș Durumuna göre t Testi Sonuçları

\begin{tabular}{|c|c|c|c|c|c|c|c|}
\hline & $\begin{array}{l}\text { Kardeş } \\
\text { Durumu }\end{array}$ & $\mathbf{n}$ & $\bar{X}$ & $S$ & sd & $\mathbf{t}$ & $\mathbf{P}$ \\
\hline \multirow{2}{*}{$\begin{array}{l}\text { İşbirlikli } \\
\text { katılım }\end{array}$} & Var & 128 & 24,60 & 3,95 & \multirow{2}{*}{198} & \multirow{2}{*}{1,09} & \multirow{2}{*}{0,27} \\
\hline & Yok & 72 & 25,22 & 3,65 & & & \\
\hline \multirow{2}{*}{$\begin{array}{l}\text { Okuldan } \\
\text { kaçınma }\end{array}$} & Var & 128 & 4,71 & 1,44 & \multirow{2}{*}{198} & \multirow{2}{*}{$-1,45$} & \multirow{2}{*}{0,14} \\
\hline & Yok & 72 & 4,41 & 1,34 & & & \\
\hline \multirow{2}{*}{$\begin{array}{l}\text { Kendi kendini } \\
\text { yönetme }\end{array}$} & Var & 128 & 8,32 & 1,51 & \multirow{2}{*}{198} & \multirow{2}{*}{$-0,33$} & \multirow{2}{*}{0,73} \\
\hline & Yok & 72 & 8,25 & 1,48 & & & \\
\hline \multirow[t]{2}{*}{ Okulu sevme } & Var & 128 & 10,56 & 1,06 & \multirow{2}{*}{198} & \multirow{2}{*}{$-0,45$} & \multirow{2}{*}{0,65} \\
\hline & Yok & 72 & 10,48 & 1,27 & & & \\
\hline \multirow{2}{*}{$\begin{array}{l}\text { Genel uyum } \\
\text { düzeyi }\end{array}$} & Var & 128 & 52,17 & 5,32 & \multirow{2}{*}{198} & \multirow{2}{*}{$-0,09$} & \multirow{2}{*}{0,92} \\
\hline & Yok & 72 & 52,09 & 5,33 & & & \\
\hline
\end{tabular}


Tablo 5’e göre, okul öncesi dönem çocukların kardeş durumu ile okula uyum ölçeği puanları arasında anlamlı bir fark bulunmamıștır.

Tablo 6. Çocuklar için Kısa Mizaç Ölçeği ve Okul Uyumu Öğretmen Değerlendirme Ölçeği Puanları Pearson Korelasyon Katsayısı Sonuçları

\begin{tabular}{lccccc}
\hline & $\begin{array}{l}\text { Iş̧birlikli } \\
\text { katılım }\end{array}$ & $\begin{array}{c}\text { Okuldan } \\
\text { kaçınma }\end{array}$ & $\begin{array}{c}\text { Kendini } \\
\text { yönetme }\end{array}$ & $\begin{array}{c}\text { Okulu } \\
\text { sevme }\end{array}$ & $\begin{array}{c}\text { Genel uyum } \\
\text { düzeyi }\end{array}$ \\
\hline $\begin{array}{l}\text { Sıcakkanlılık- } \\
\text { utangaçlık }\end{array}$ & 0,095 & 0,110 & $-0,001$ & $-0,062$ & 0,092 \\
\hline Sebatkarlık & 0,160 & $-0,079$ & 0,044 & 0,088 & 0,067 \\
\hline Ritmiklik & $-0,001$ & 0,106 & $-0,178^{*}$ & $-0,064$ & $-0,038$ \\
\hline Tepkisellik & $-0,032$ & $-0,031$ & $-0,029$ & $-0,061$ & $-0,063$ \\
\hline $\begin{array}{l}\text { Genel mizaç } \\
\text { düzeyi }\end{array}$ & 0,052 & 0,011 & $-0,047$ & $-0,037$ & 0,007 \\
\hline
\end{tabular}

${ }^{*} \mathrm{p}<.05$

Tablo 6'ya göre okul öncesi dönem çocukların çocuklar için kısa mizaç ölçeği alt boyutlarından ritmiklik ile okula uyum ölçeği kendi kendini yönetme alt boyutu arasında olumsuz yönde anlamlı ilişki bulunmuştur $(\mathrm{r}=-0.178, \mathrm{p}<.05)$. Diğer boyutlar arasında anlamlı bir ilişki bulunmamıştır.

Tablo 7. Cassidy Kukla Görüșme Formu ve Okul Uyumu Öğretmen Değerlendirme Ölçeği Puanları Pearson Korelasyon Katsayısı Sonuçları

\begin{tabular}{lccccc}
\hline & $\begin{array}{c}\text { İşbirlikli } \\
\text { katılım }\end{array}$ & $\begin{array}{c}\text { Okuldan } \\
\text { kaçınma }\end{array}$ & $\begin{array}{c}\text { Kendini } \\
\text { yönetme }\end{array}$ & $\begin{array}{c}\text { Okulu } \\
\text { sevme }\end{array}$ & $\begin{array}{c}\text { Genel } \\
\text { uyum } \\
\text { düzeyi }\end{array}$ \\
\hline Benliğin olumluluğu & $-0,128$ & 0,047 & $-0,097$ & $-0,019$ & $-0,112$ \\
\hline Benliğin açıklı̆ı & $-0,104$ & $-0,103$ & 0,043 & 0,007 & $-0,089$ \\
\hline Genel özsaygı düzeyi & 0,107 & $-0,014$ & $0,142^{*}$ & $-0,014$ & 0,103 \\
\hline
\end{tabular}

*p $<.05$

Tablo 7'de görüldüğü gibi okul öncesi dönem çocukların genel özsaygı puanları ile okula uyum ölçeği kendi kendini yönetme alt boyutu puanları arasında olumlu yönde anlamlı bir ilişki bulunmuştur ( $\mathrm{r}=0.142$, p<.05). Diğer boyutlar arasında anlamlı bir ilişki bulunmamıștır.

Tablo 8. Okula Uyum Düzeyinin Yordanmasına İlişkin Çoklu Regresyon Analizi Sonuçları

\begin{tabular}{llllll}
\hline & $\mathrm{B}$ & $\mathrm{Std}$. hata & $\mathrm{Beta}$ & $\mathrm{t}$ & $\mathrm{p}$ \\
\hline Sabit & 52,398 & 4,075 & - & 12,858 & 0,00 \\
\hline Sıcakkanlılık-utangaçlık & 0,110 & 0,100 & 0,89 & 1,100 & 0,273 \\
\hline Sebatkarlık & 0,061 & 0,072 & 0,064 & 0,850 & 0,396 \\
\hline Ritmiklik & $-0,081$ & 0,112 & $-0,057$ & $-0,722$ & 0,471 \\
\hline Tepkisellik & $-0,41$ & 0,047 & $-0,063$ & $-0,866$ & 0,388 \\
\hline Benliğin olumluluğu & $-0,264$ & 0,354 & $-0,072$ & $-0,746$ & 0,457 \\
\hline Benliğin açıklı̆̆ı & $-0,300$ & 0,249 & $-0,086$ & $-1,201$ & 0,231 \\
\hline
\end{tabular}

$\mathrm{R}^{2}=0,392 \quad \mathrm{DW}=1,774 \quad \mathrm{~F}=1,094 \quad \mathrm{p}=0,368$

Regresyon modelinin geçerliliğini test etmek amacı ile Durbin-Watson Testi yapılmış ve değeri 1.774 olarak bulunmuştur. Bu değere göre Çoklu regresyon modeli için bağımsız değişkenler arasında oto korelasyon bulunmadığı söylenebilir. Regresyon Analizi için bağımsız değişkenler arasında oto korelasyonun olmaması istenen bir durumdur. Durbin-Watson 
değerinin bir regresyon analizi için 1.5 ile 2.5 arasında olmasının yeterli olduğu belirtilmektedir (Büyüköztürk ve diğerleri, 2010 ).

Tablo 8'e göre okul öncesi dönem çocukların okula uyum düzeylerinin kestiricisi olarak düşünülen mizaç ve öz saygı bağımsız değişkenleri yordama modeli uygun değildir $(F=1,094 p$ $>$.05). Okul öncesi dönem çocuklarının mizaç özellikleri ile öz saygı düzeyleri çocukların okula uyum düzeylerini açılama oranı \%3' dür. Bu oran oldukça düşük bulunmuştur. Bir başka deyişle okul öncesi dönem çocuklarının okula uyum düzeylerini mizaç ve özsaygı değişkenlerinden farklı bazı değişkenlerin etkilerinin söz konusu olduğu söylenebilir.

\section{TARTIŞMA ve SONUÇ}

Araştırmada Okul Uyumu Öğretmen Değerlendirme Ölçeği işbirlikli katılım, kendi kendini yönetme ve genel uyum düzeyi alt boyutlarında, kız çocukların lehine anlamlı farklılıklar bulunmuștur. Buna göre kız çocuklarının okula uyum sağlama düzeylerinin erkek çocuklara kıyasla daha yüksek olduğu söylenebilir. Bu çalışmanın bulgularına paralel olarak Ramey, Lanzi, Phillips ve Ramey (1998) cinsiyetin okul başarısı ve okula uyum ile ilişkili önemli bir değişken olduğunu ve kız çocuklarının akademik başarı ve uyum seviyelerinin daha yüksek olduğunu ortaya koymuşlardır. Çimen (2000) çalışmasında, psiko-sosyal gelişimde cinsiyet değişkeninin etkili olduğunu ve kız öğrencilerin bağımsız faaliyet gösterebilme ve sorumluluk puan ortalamalarının erkek öğrencilerden fazla olduğunu bulmuştur. Bahalı, Tahiroğlu ve Avcı (2009) okul öncesi dönemde okul olgunluğunu etkileyen faktörleri incelediği araştırmada kız çocukların lehine sonuçlar bulmuşlardır. Ancak alan yazında okul öncesi dönem çocukları ile yapılan ve okula uyum, okul olgunluğu ve cinsiyet arasında bir ilişki bulunmayan çalıșmalar da yer almaktadır (Çılkrıkçı,1999; Yoleri, 2014b,c).

Yaş değişkenine göre bulgulara bakıldığında çalışmada okula uyum ölçeği işbirlikli katılım ve genel uyum düzeyi alt boyutlarında, büyük yaş grubu çocukların lehine anlamlı farklılık bulunmuştur. Buna göre büyük yaş grubundaki (60-72 ay) çocukların küçük yaş grubuna göre (45-60 ay) okula uyum puanlarının daha yüksek olduğu ifade edilebilir. Çalışmanın bulgularına paralel olarak Gülay-Ogelman ve Erten-Sarıkaya (2013) tarafından yapılan çalışmada, altı yaşındaki çocukların okulu sevme düzeylerinin beş yaşındaki çocuklardan yüksek olduğu görülmektedir. Bu bulgunun çocukların yaş ile birlikte gelişimsel olarak olgunlaşmaları ile ilgili olarak beklenen bir sonuç olduğu düşünülebilir.

Okula devam süresi ve okula uyum arasındaki ilişkiye bakıldığında okulu sevme, işbirlikli katılım, okuldan kaçınma, kendi kendini yönetme ve genel uyum puanlarında okula devam süresinin tek başına belirleyici bir değişken olmadığı görülmektedir. Okula devam süresi içinde okuldan kaçınma alt boyutu puanlarında belli bir dönemde artış daha sonra azalma gözlenmektedir. Bu bulgu uyumun dinamik bir süreç olduğunu ve süreç içinde okula devam süresinin yanında okulun ve çocuğun özelliklerinden kaynaklanan farklı faktörlerinin etkisinin olabileceğini göstermektedir. Bu çalışmanın bulgularından farklı olarak Bracken ve Fischel (2007) Head Start eğitimi alan çocukların sosyal becerilerinin davranış problemleri ve okul olgunluğu üzerine etkisini inceledikleri çalışmalarında; dört yaşından itibaren okul öncesi eğitim kurumlarına giden sosyal beceri ve davranış sorunları olan çocukların; sosyal becerilerinin okul öncesi eğitim süresi boyunca geliştiğini ve sözel ve matematik becerileri de olumlu yönde gelişerek okula hazır oldukları saptanmıştır. Çalışmada okula devam süresinin okul olgunluğunu etkileyen bir değişken olduğu vurgulanmıştır. Claes (2010) okul öncesi eğitimin diğer eğitim kademelerinde uyum sürecine etkisini incelediği araştırmasında, ilkokula bağlı okul öncesi sınıflarında eğitim alan çocukların okula uyum ölçeği puanlarının daha önce okul öncesi eğitim almamıș çocuklardan olumlu yönde anlamlı derecede farklı olduğu sonucuna ulașılmıștır. Gülay (2011) okula uyum düzeyleri ve akran ilişkilerinin farklı boyutları arasındaki ilişkiyi eğitim öğretim yılının güz ve bahar dönemlerinde izlemiştir. Araştırmanın sonuçlarına göre güz ve bahar dönemlerinde, çocukların okula uyum düzeyleri yükseldikçe, olumlu sosyal davranış düzeyi de yükselmektedir. Al-Hendawi ve Reed (2012) risk altındaki çocuklarla gerçekleştirdiği çalışmada okula devam ve aktivite seviyesinin akademik başarı ile anlamlı bir ilişkisi olduğunu belirtmiştir. Bu bulgular okul öncesi eğitimden yararlanmış olma ve okula devam süresinin okula uyum ile 
ilgili bir değişken olduğunu göstermektedir. Bununla birlikte bu çalışmanın bulguları da dikkate alındığında okul öncesi eğitimin niteliğinin çok önemli bir unsur olduğu söylenebilir (Derman ve Başal, 2010).

Okula uyum ölçeği puanlarında kardeş durumu değişkeni ile ilgili olarak anlamlı bir farklılık bulunmamıştır. Çalışmanın bulgularına paralel olarak Topçu (2012) ilkokul birinci sınıf çocuklarının yer aldığı araştırmasında okula uyum düzeyi ile kardeş sayısı değişkeni arasında anlamlı bir fark bulamamıștır. Benzer bir șekilde Balkaya ve Tuğrul (1998) okul öncesi dönem çocuklarının kardeş sayısı ve okula uyumu arasında ilişki olmadığını ifade ederken Bomb'da (2005) araştırmasında kardeşi olan ve olmayan gruplar arasında problem ve prososyal davranışlar açısından farklılık olmadığını göstermiştir. Buna karşılık Laffey-Ardley ve Thorpe (2005) ikizlerin sosyal beceri ve arkadaşlık ilişkileri puanlarının araştırmaya katılan tek çocuklara göre düşük olduğunu bulmuştur. Çalışmanın bulgularına benzer çalışmalar kardeș değişkeninin okula uyumda belirleyici bir değişken olmadığını gösterirken aksi yönde bulguların da alan yazında yer alması kardeş değişkeni ile ilişkili belirsiz bazı özelliklerin bulunması ile açıklanabilir. Doğum sırası, kardeşler arasındaki yaş farkı, etkileşimin niteliği gibi bu özellikler çalışmadan çalışmaya değişebilmektedir. Bu nedenle bulgular arasında farklılıklar olabilmektedir.

Çocukların mizacı ve okula uyum özelliklerine ilişkin olarak bulgular incelendiğinde uyum ölçeği kendi kendini yönetme alt boyutu puanları ile mizaç ölçeği ritmiklik alt boyutu puanları arasında olumsuz yönde anlamlı bir ilişki bulunmuştur. Çalışmada kendi kendini yönetme boyutu dışında mizacın boyutları ile okula uyum arasında anlamlı bir ilişki bulunmamıştır. Alan yazında mizacın okula uyum ile dolaylı ilişkisini gösteren çalışmalar yer almaktadır. Goldsmith, Aksan, Essex, Smider ve Vandell (2001) okul öncesi dönemdeki çocukların mizaç ile anaokulu davranışları arasındaki sosyal olgunluğun aracı değişken olarak yer aldığı dolaylı bir ilişki bulmuştur. Olumsuz tepkisellik düzeyi yüksek olan çocuklarda daha az olgunlaşmış ve daha yıkıcı davranışlar gösterme eğilimi olduğu görülmektedir. Ayrıca olumlu duygulanım ve sebat ile sosyal olgunluğun ilişkili olduğu bulunmuştur. Sanson, Hemphill ve Smart (2002) da sosyal yeterlilik üzerinde mizacın doğrudan etkilerini belirtmiștir. Mendez, Fantuzzo ve Cicchetti (2002) utangaç/içe dönük mizaç özellikleri ile çocukların yalnızlık, düşük sosyal yeterlik ve akran şiddetine maruz kalma riski ile karşı karşıya olduklarını göstermektedir. Blair, Denham, Kochanoff ve Whipple (2004) çalışmalarında okul öncesi dönem çocuklarında sosyal yeterlilik ve davranış sorunlarının gelişiminde mizaç özellikleri ve duygusal başa çıkma stratejilerinin etkilerini araştırmıştır. Duygu ile baş edebilme yeteneğinin olumlu sosyal davranışların geliştirilmesinde mizaç özelliklerinden daha önemli olduğu ifade edilmiştir. Özellikle, pasif başa çıkma stratejilerinin kullanımı davranış sorunları ve mizacın boyutları arasındaki ilişkide belirleyici olmaktadır. Valiente, Swanson ve Chalfant (2012) okul öncesi dönem çocuklarda mizaç, sınıfa katılım ve öğrenci öğretmen ilișkilerini inceledikleri araștırmalarında kendini kontrol etme becerisi ölçeklerdeki olumlu alt boyutlarla uyum gösterirken, dürtüsellik ise ölçeklerdeki olumsuz alt boyutlarla uyum sağlamaktadır. Kendini kontrol etme becerisi düşük olan çocukların öğretmen-öğrenci ilişkisinin zayıf olduğu sonucuna varılmıştır. Çalışmada ritmiklik alt boyutu dışında mizacın boyutları ile okula uyum arasında anlamlı bir ilişki bulunmamış olması okula uyum ile ilişkili daha belirleyici değişkenlerin varlı̆̆ ile açıklanabilir.

Alan yazında mizaç ile okula uyum ve akademik başarı arasında anlamlı ilişkileri gösteren çalışmalar da yer almaktadır. Reed-Victor (2004) çalışmasının bulgularına göre mizaç boyutları (Olumsuz duygulanım, Sebat, engellenme ve aktiflik) ile kişilik boyutlarının (dışa dönüklük, yönetilebilirlik ve açıklık / sorumluluk) çocukların okula uyum düzeylerinde ve sosyal becerilerin gelişiminde önemli ölçüde belirleyici olduğunu ifade etmiştir. Benzer bir şekilde Zupancic ve Kavcic (2011), okul öncesi dönem çocukların kişisel özelliklerinin okula uyum üzerinde etkili olduğu sonucuna varmışlardır. Ayrıca utangaçlık ve tepkiselliğin akademik başarı ve okula uyum ile ilişkili olduğu bulunmuştur (Seven, 2010; Stoeckli, 2010; Valiente, Lemery-Chalfant ve Swanson, 2010). Boström, Broberg ve Bodin (2011) akademik başarısı düşük çocukların diğer çocuklara göre olumsuz davranışları destekleyen farklı mizaç tiplerine sahip olduğunu belirtmektedirler. 
Çocukların özsaygı düzeylerine göre bakıldığında okula uyum ölçeği kendi kendini yönetme alt boyutu puanları ile genel özsaygı düzeyi puanları arasında olumlu yönde anlamlı bir ilișki bulunmuştur. Okula uyumun alt boyutlarından kendi kendini yönetme özelliğinin özsaygı ile ilişkili olarak ön plana çıktı̆̆ı görülmektedir. Buna göre özsaygı düzeyi yüksek çocukların kendi kendini yönetme becerisi gösterdikleri söylenebilir. Verschuren, Marcoan ve Schoefs (1996) okul öncesi dönem çocukları ile yaptıkları çalışmada özsaygı düzeyi yüksek olan çocukların anne ile güvenli bağlılık ilişkisi kurdukları, kendi kusurlarını açıça kabul ettikleri saptanmıştır. Benzer bir şekilde Turaşlı (2006) tarafından gerçekleștirilen araştırma sonucunda benlik algıları desteklenen okul öncesi çocuklarının zihinsel bakımdan hazır bulunuşluklarının arttığı, aynı zamanda bu durumun sosyal duygusal uyum düzeylerini de artırdığı saptanmıştır. Şahan (2008) akademik başarının öğretmen-öğrenci ilişkisinden, benlik algısı ve okul tutumundan etkilendiğini ortaya koymuştur.

Okul öncesi dönem çocuklarının mizaç özellikleri ile öz saygı düzeylerinin birlikte çocukların okula uyum düzeylerini açıklama oranı \%3' dür. Bu oran oldukça düşük olduğu için çocukların okula uyum düzeylerini etkileyebilecek başka değişkenler olduğu söylenebilir. Orçan ve Deniz (2004) okul öncesi eğitimine devam eden çocukların sosyal uyumlarını incelediği araştırmasında annenin eğitim düzeyi arttıkça çocukların sosyal uyum puanlarında artış olduğu sonucuna ulaşmıştır. Diğer bir araştırmada Chen, Chang, He ve Lui (2005) çalışmasında aile ile ilişkili değişkenleri odak almış ve anne babalarıyla ilişkileri olumlu olan Çinli çocukların liderlik, sosyal yeterlik ve sosyal beceri yönünden daha olumlu oldukları ve okula daha kolay uyum sağladıkları bulunmuştur.

Tüm bu bulgular ışığında okul öncesi dönem çocuklarının okula uyum düzeylerine bakıldığında cinsiyet, mizaç ve özsaygı değişkenleri ile ilişkili olabileceği ancak okula uyumu etkileyebilecek aile ve okul ile ilişkili faktörlerin; anne-baba tutumları, sosyo-ekonomik düzey, öğretmen, okul ortamı, okulun uyguladı̆̆ı uyum programı gibi değişkenlerin bu araştırmada yer almaması çalışmanın sınırlılığı olarak belirtilebilir. Bu doğrultuda; okul öncesi dönem çocuklarının okula uyum düzeylerini etkileyebilen çocuk, okul ve aileye ilişkin değişkenlerin birlikte incelendiği çalışmalar yapılması önerilebilir. Bu değişkenler belirlenirken çocuğun doğum sırası, anne baba çocuk etkileşimin niteliği gibi detaylı özelliklerin dikkate alınması elde edilen bulguları zenginleştirebilecektir. Ayrıca sonraki çalışmalarda okula uyumun öğretmen bakış açısı dışında gözlem, görüşme gibi çoklu bilgi toplama yöntemleri kullanılarak değerlendirilmesi ve boylamsal çalışmalar yapılması okula uyum sürecinin süreç içindeki gelişimini belirleme amacıyla önem taşımaktadır. Ek olarak okula uyumu etkileyen değişkenlerin belirlenerek uyumu destekleyen programların geliştirilmesi ve deneysel çalışmalarla sınanması önerilebilir. $\mathrm{Bu}$ çalışmada mizaç, özsaygı ve okula uyum arasında doğrudan bir ilişki olup olmadığı belirlenmeye çalışılmıştır. Sonraki çalışmalarda başa çıkma becerileri, özdüzenleme, duygu düzenleme, sosyal yeterlik gibi aracı değişkenler ile bir model kurularak modelin test edilmesi önerilmektedir.

\section{KAYNAKÇA}

Al-Hendawi, M. \& Reed, E. (2012). Education outcomes for children at-risk: The influence of individual differences in children's temperaments. International Journal of Special Education, 2, 64-72.

Balkaya, İ. \& Tuğrul, B. (1998). Anaokuluna yeni başlayan çocukların okula uyum süreçlerini etkileyen faktörlerin incelenmesi. Hacettepe Üniversitesi Ev Ekonomisi Yüksek Okulları Yayınları, 2, 145-150.

Bahalı, K., Tahiroğlu, A. \& Avcl, A. (2009). Okul reddi olan çocuk ve ergenlerin klinik özellikleri. Anadolu Psikiyatri Dergisi, 10, 310-317.

Baydar, N., Küntay, A., Gökşen, F., Yağmurlu, B. \& Cemalcılar, Z. (2008). [Türkiye'de Erken Çocukluk Gelişim Ekolojileri (TEÇGE) Çalışması-1.Tur Verileri]. http://portal.ku.edu.tr/ tecge/index.htm adresinden 01 Aralı 2015 tarihinde indirilmiştir.

Birch, S. H., \& Ladd, G. W. (1997). The teacher-child relationship and children's early school adjustment. Journal of School Psychology, 34(1), 61-79.

Blair, K.A., Denham, S.A., Kochanoff, A., \& Whipple, B. (2004). Playing it cool: Temperament, emotion regulation, and social behavior in preschoolers. Journal of School Psychology, 42(6), 419-443. 
Bracken, S., \& Fischel, J. (2007). Relationships between social skills, behavioral problems, and school readiness for head start children. A Research to Practice Journal for the Early Childhood Field, 10, 109126.

Bomb, P. (2005). Social skills and siblings in India. (Master Thesis). University of Missouri. Columbia.

Boström, P.K., Broberg, M. \& Bodin, L. (2011). Child's positive and negative impacts on parents: A personoriented approach to understanding temperament in preschool children with intellectual disabilities. Research in Developmental Disabilities, 32, 1860-1871

Büyüköztürk, Ş., Çakmak, E. K., Akgün, Ö. E., Karadeniz, Ş. \& Demirel, F. (2010). Bilimsel Araştırma Yöntemleri. Ankara: Pegem Yayıncılık.

Chen, X., Chang, L., He, Y. \& Liu, H. (2005). The peer group as a context: Moderating effects on relations between maternal parenting and social and school adjustment in Chinese children. Child Development, 2, (76), 417-434.

Chess, S., \& Thomas, A. (1986). Temperament in Clinical Practices. New York, NY: The Guilford Press.

Claes, B. (2010). Transition to kindergarten: The impact of preschool on kindergarten adjustment. (Master Thesis). Alfred University. New York.

Coolahan, K., Fantuzzo, J., Mendez, J., \& McDermott, P. (2000). Preschool peer interactions and readiness to learn: Relationships between classroom peer play and learning behaviors and conduct. Journal of Educational Psychology, 92(3), 458-465.

Curby, T.W., Rudasill, K.M., Edwards, T. \& Koraly, P.E. (2011). The role of classroom quality in ameliorating the academic and social risks associated with difficult temperament. School Psychology Quarterly, 26(2), 175-188.

Çıkrıkçı, S. (1999). Ankara ili merkezinde resmi banka anaokullarına devam eden 5-6 yaş çocuklarının okul olgunluğu ile aile tutumu arasındaki ilișkinin incelenmesi. (Yayımlanmamış Yüksek Lisans tezi). Gazi Üniversitesi. Ankara.

Çimen, S. (2000). Ankara'da üniversite anaokullarına devam eden beş-altı yaş çocuklarının psiko-sosyal gelişimlerinin incelenmesi. (Yayımlanmamış Yüksek Lisans tezi). Ankara Üniversitesi, Ankara.

Derman, M. T., \& Başal, H. A. (2010). Cumhuriyetin ilanından günümüze Türkiye'de okul öncesi eğitim ve ilköğretimde niceliksel ve niteliksel gelişmeler. Uluslararası Sosyal Araştırmalar Dergisi, 3(11), 560569.

Dikici, A. (1998). Cassidy kukla görüşme formunun 5-6 yaş çocuklarına uyarlanması ve özsaygı düzeylerinin incelenmesi. (Yayımlanmamış Yüksek Lisans tezi). Ankara Üniversitesi, Ankara.

Docckett, S. \& Perry, B. (2003). The transition to school what's important. Educational Leadership. 60(7), 30-33.

Dündar, B. (2010). Okulöncesi dönem 6 yaş çocuklarının benlik algıları ile bilişsel performansları arasındaki ilişki. (Yayımlanmamış Yüksek Lisans tezi). İstanbul Üniversitesi. İstanbul.

Eisenberg, N., Valiente, C., Spinrad, T.L., Liew, J., Losoya, S.H., Reiser, M., \& Cumberland, A. (2009). Longitudinal relations of children's effortful control, impulsivity, and negative emotionality to their externalizing, internalizing, and co-occurring behavior problems. Developmental Psychology, 45(4), 988-1008.

Erkan, S. (2011). Farklı sosyoekonomik düzeydeki ilköğretim birinci sınıf öğrencilerinin okula hazır bulunuşluklarının incelenmesi. Hacettepe Üniversitesi Ĕ̆itim Fakültesi Dergisi, 40(40).

Gleason, T.R., Gower, A.L., Hohmann, L.M., \& Gleason, T.C. (2005). Temperament and friendship in preschool-aged children. International Journal of Behavioral Development, 29(4), 336-344.

Goldsmith, H. H., Aksan, N., Essex, M., Smider, N. A. \& Vandell, D. L. (2001). Temperament and socioemotional adjustment to kindergarten: A multi-informant perspective, In: T. D. Wachs \& G. A. Kohstamm (Eds.), Temperament in Context (pp.103-138). Mahwah, NJ: Erlbaum.

Gülay, H. (2011). Anasınıfına devam eden 5-6 yaş grubu çocuklarının okula uyumlarının sosyal beceriler açısından incelenmesi. NWSA E-Journal of New World Sciences Academy, 6(1), 139-146.

Gülay-Ogelman, H., \& Erten-Sarıkaya, H. (2013). Okul öncesi eğitimi almış çocukların okula uyum düzeylerinin 5 ve 6 yaşta incelenmesi: İki yıllık boylamsal çalışma. The Journal of Academic Social Science Studies, 6(7), 417-434.

İkiz, H. (2009). 6 yaş grubundaki çocukların benlik algıları ile aile işlevleri arasındaki ilişkinin incelemesi. (Yayımlanmamış Yüksek Lisans tezi). Marmara Üniversitesi, İstanbul.

Inan, H. Z., \& Inan, T. (2015). 3 H s Education: Examining hands-on, heads-on and hearts-on early childhood science education. International Journal of Science Education, 37(12), 1974-1991.

Joyce, D. (2010). Essentials of temperament assessment. In: A. S. Kaufman \& N. L. Kaufman, (Series Eds.), Essentials of Psychological Assessment Series. NJ: Wiley \& Sons Inc.

Kagan J. (2002). Biology, context, and developmental inquiry. Annual Review of Psychology, 54, 1-23. 
Ladd, G. W., Kochenderfer, B. J., \& Coleman, C. C. (1996). Friendship quality as a predictor of young children's early school adjustment. Child Development, 67(3), 1103-1118.

Kristal, J. (2005). The temperament perspective: Working with children's behavioral styles. Baltimore: Brookes Publishing.

Liew, J., McTigue, E., Barrois, L., \& Hughes, J. (2008). Adaptive and effortful control and academic self-efficacy beliefs on achievement: A longitudinal study of 1st through 3rd graders. Early Childhood Research Quarterly, 23(4), 515-526.

Lindsey, E. W. \& Colwell, M. J. (2003). Preschooler's emotional competence links to pretend and physical play, Child Study Journal, 1, 39-53.

Laffey-Ardley, S. \& Thorpe, K. (2005). Being opposite: Is there advantage for social competence and friendship in being an opposite-sex twin? Research and Human Genetics, 9(1), 131-140.

Mendez, J., Fantuzzo, J., \& Cicchetti, D. (2002). Profiles of social competence among low-income African American preschool children. Child Development, 73(4), 1085-1100.

Oktay, A. \& Polat-Unutkan, Ö. (2005). Okul Öncesi Eğitimde Güncel Konular. İstanbul:Yaylacık Matbaası.

Orçan, M., \& Deniz, E. (2004). Anaokuluna devam eden altı yaş çocuklarının sosyal uyumlarının incelenmesi. Marmara Üniversitesi Atatürk Eğitimi Fakültesi I. Uluslar arası Okul Öncesi Eğitimi Kongresi Bildiri Kitabı, 2, 310-321.

Önder, A., \& Gülay, H., (2010). Reliability and validity of the teacher rating scale of school adjustment for 56 years of children. International Online Journal of Educational Sciences, 2(1), 204-224.

Prior, M.R. Sanson, A.V. \& Oberklaid, F. (1989). The Australian temperament project. In: G.A. Kohnstamm, J.E.Bates, M.K. Rothbart, (Eds.), Temperament in Childhood. (pp.537-554). Oxford, England: John Wiley \& Sons.

Ramey, S.L., Lanzi, R.G., Phillips, M.M., \& Ramey, C.T. (1998). Perspectives of former Head Start children and their parents on school and the transition to school. The Elementary School Journal, 98(4), 311-327.

Reed-Victor, E. (2004). Individual differences and early school adjustment: Teacher appraisals of young children with special needs. Early Child Development and Care, 174(1), 59-79.

Rothbart, M.K., Ahadi, S.A. \& Evans, D.E. (2000). Temperament and personality: Origins and outcomes. Journal of Personality and Social Psychology, 78(1), 122-135.

Rothbart, M. K., Derryberry, D. \& Hershey, K. (2000). Stability of temperament in childhood: Laboratory infant assessment to parent report at seven years, In: V. J. Molfese \& D. L. Molfeses (Eds.), Temperament And Personality Development Across The Life Span (pp.85-119), Hillsdale, NJ: Erlbaum.

Rutter, M. (1987). Temperament: Conceptual issues and clinical implications, American Journal of Orthopsychiatry, 57, 316-331.

Sanson, A., Hemphill, S. A., \& Smart, D. (2002). Temperament and social development. In P. K. Smith, \& C. H. Hart (Eds.), Blackwell Handbook of Childhood Social Development, (pp. 97- 115). Malden, Blackwell Publishers.

Sarıca, Ö. (2010). Okul öncesi eğitim kurumlarına devam eden 5 ve 6 yaş grubu çocuklarının benlik kavramlarının çeşitli sosyo-demografik değişkenlere göre incelenmesi. (Yayımlanmamış Yüksek Lisans tezi). Maltepe Üniversitesi, İstanbul.

Schunf, D. H. (2009). Öğrenme Teorileri- Eğitimsel bir bakıșla. (Çev.M. Șahin). Ankara: Nobel Yayın Dağıtım.

Seven, S. (2010). Attachment and social behaviors in the period of transition from preschool to first grade. Social Behavior and Personality, 38(3), 347-356.

Stoeckli, G. (2010). The role of individual and social factors in classroom loneliness. The Journal of Educational Research, 103(1), 28-39.

Strelau, J. (2002). Temperament A Psychological Perspective. NY: Kluwer Academic Publishers.

Şahan, K. (2008). The role of perceived teacher acceptance-rejection on student's self concept, school attitude and academic achievement. (Yayımlanmamış Yüksek Lisans tezi). Boğaziçi Üniversitesi, İstanbul.

Şanlı, Z. S. (2012). Probleme dayalı altı aşamalı ders işleme modeli'nin anaokuluna giden 60-72 aylık çocukların benlik algılarına etkisi. (Yayımlanmamış Yüksek Lisans tezi). Hacettepe Üniversitesi, Ankara.

Turaşlı, N. (2006). 6 Yaş grubu çocuklarda benlik algısını desteklemeye yönelik sosyal-duygusal hazırlık programının etkisinin incelenmesi. (Yayımlanmamış Doktora tezi). Marmara Üniversitesi, İstanbul.

Topçu, Z. (2012). Okul öncesi eğitimin ilköğretim birinci sınıföğrencilerinin okula uyum becerilerine ve Türkçe dil becerilerine etkisi. (Yayımlanmamış Yüksek Lisans tezi). Hacettepe Üniversitesi, Ankara.

UNICEF, (2012). School Readiness: A conceptual framework. http://www.unicef.org/education/files/

Chil2Child_ConceptualFramework_FINAL(1).pdf adresinden 25 Ocak 2016 tarihinde indirilmiştir.

Verschuren, K., Marcoan, A., \& Schoefs, V. (1996). The internal working model of the self, attachment, and competence in 5 years old. Child Development, 50, 2493- 2511. 
Valiente, C., Lemery-Chalfant, K.S., \& Swanson, J. (2010). Prediction of kindergartners' academic achievement from their effortful control and negative emotionality: Evidence for direct and moderated relations. Journal of Educational Psychology, 102(3), 550-560.

Valiente, C., Swanson, J. \& Chalfant, K. L. (2012). Kindergartners' temperament, classroom engagement, and student- teacher relationship: Moderation by effortful control. Social Development, 21, (3), 558- 576.

Yağmurlu, B. ve Sanson, A. (2004). The relations between parenting stress, goals and practices, and child temperament: Evidence from Australia. International Journal of Psychology. Abstracts of the International Congress of Psychology, 39, 388.

Yoleri, S. (2014a). The relationship between temperament, gender and behavioural problems in preschool children. South African Journal of Education, 34(2), 1-18.

Yoleri, S. (2014b). The effects of age, gender, and temperament traits on school adjustment for preschool children. E-International Journal of Educational Research, 5 (2), 54-66.

Yoleri, S. (2014c). Preschool children's school adjustment: Indicators of behaviour problems, gender, and peer victimization. Education 3-13: International Journal of Primary, Elementary and Early Years Education, 1-11.

Zhou, Q., Main, A., \& Wang, Y. (2010). The relations of temperamental effortful control and anger/frustration to Chinese children's academic achievement and social adjustment: A longitudinal study. Journal of Educational Psychology, 102(1), 180-196.

Zupancic, M., \& Kavcic, T. (2011). Factor of social adjustment to school: Child's personality, family and preschool. Early Child Development and Care, 181(4), 493-504. 